DOI :

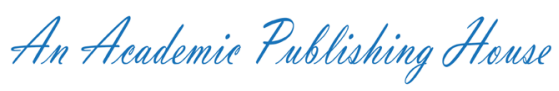

\title{
Black Urban Writing in Toni Morrison's Novels
}

\author{
Shi Long
}

College of Foreign Language, Pingdingshan University, Pingdingshan, China.

\begin{abstract}
Toni Morrison's black urban writing focuses on American blacks inequality in urban survival and mental situation, Morrison's novels is characterized with sharp contrast of black personal experiences in city and different urban landscape, as well as the reaching of the spiritual appeal of urban blacks through art, in order to highlight the reconstruction of the spiritual home after the black mental and physical double injury in the city.
\end{abstract}

KEYWORDS: Toni Morrison; novels; Black urban writing

\section{THE INTRODUCTION}

The existence of Afro-American literature is based on national culture, and Afro-American fiction is a cultural symbol that can best represent the characteristics of Afro-American. After world War II, the themes of black literature were no longer limited to denouncing the history of black humiliation in the plantations, but to further explore the living conditions of black people in a more complex urban environment. Born in a small town in Ohio, Toni Morrison moved around as her life changed. She worked at Texas Southern University, then Howard University in Washington. In 1964, Morrison moved to New York and later taught at Princeton University in New Jersey. This dynamic change of urban space makes Morrison have a deep experience of black people's life in the city. Toni Morrison's early novels reflect the profound influence of the early Black Americans under the oppression of slavery, while her later novels focus on the urban conditions of black people. Among Toni Morrison's works, predominantly black urban novels such as Song of Solomon, Jazz, The Bluest Eye, God Help the Child, and Home are particularly worthy of study.

\section{THE PERSONAL EXPERIENCE OF URBAN BLACK PEOPLE CHARACTERIZED BY SHARP OPPOSITION}

\section{The Opposition between Urban and Rural}

There have been two booms of urbanization for African America. The first was the influx of Southern blacks into southern cities after the Civil War. However, they rarely get job opportunities, so some enterprising young people go to the northern cities to find their way. The second wave began in the early 20th century, when more blacks left the South and moved to the Northeast and Midwest. There were two upsurges of African American migration to the west and north. The first surge came during World War I, called the First Migration of Blacks. After World War II, black migration resumed because of a shortage of urban labor in the north and West. The second peak of the Great Black Migration occurred in the 1940s, when large numbers of black people moved to the north and west of the United States. Why do black people go to cities? From the perspective of internal causes, the natural disasters in the south greatly affected the agriculture in the south and the discrimination suffered by the black people in the south are the direct reasons for the black people to emigrate. From the perspective of external factors, due to the extreme shortage of labor in the north, a large number of black labor is needed to supplement the labor market in the north. At the same time, southern blacks were attracted to the advantages of the north. By 1930, 1.3 million black people had moved from rural South to other parts of the United States. Correspondingly, the proportion of black population in large cities in the Northeast, Midwest and West Coast of the United States increased gradually. For example, the black population of New York increased by 26.9\% from 1900 to 1930.

The city is relative to the country. Morrison's black urban writing is inseparable from the memory of the past countryside and its influence on the present. "Beloved" and "A Mercy" are considered closely related companion piece. In the novels, two mothers in the southern countryside prevent their daughters from repeating their mistakes,mother kill the daughters themselves in Beloved, the mother sells her daughter to a stranger in Grace. Although the expression of maternal love in both novels is against ethics, they both trace back slavery by focusing on maternal love. The individual experience in Grace goes from rural to urban, and 
this individual experience is incorporated into the cultural experience of African Americans.

\section{The Opposition betweenin the North and South Black Cities}

Black people were free, but they had no power, no land, no money, no social status. But they were free to control their own workforce and their own families. In the Great Black Migration, the process of black migration is the process of urbanization because the black migration to the north and west mainly flows to urban areas. After the Civil War, with the rapid development of Industrialization in the United States, urbanization also entered a development peak, which was reflected in the speed of urbanization. Due to the unbalanced development of industrialization, urbanization also has obvious regional differences. Industrialization and urbanization in the south developed slowly compared with the northeast and the central and western regions. Although the economy recovered after reconstruction, urbanization in the south was still characterized by slow and some abnormal development.

In the Bluest Eye, the novel takes place in two geographical Spaces: the northern town of Lorraine, Ohio, and the southern town of Kentucky and Georgia. The Ohio River, which is related to the story, is an important geographical dividing line between the north and the south, as well as the gap between the identities of the characters. In Song of Solomon, Detroit, known as the Auto City, was a period of rapid economic development after World War II. The city naturally has different regions. The southern part in novel has become a gathering place for blacks, and the island of Glory become an area that rich people like Milkman can only enjoy, the Pilate family and black people like Guitar can only live in slums.. Atlanta, the city where the novel "Home" takes place, is a city in the South of the United States,. Even after the civil war ended in one hundred, segregation still exist obviously for the black, and the blacks living in Atlanta are also accustomed to this kind of segregation. Hundreds of years of slavery have made them accustomed to treating differently from whites. Deep-rooted racial discrimination still exists in this city, which is also the biggest difference between the the south city and the northern city.

\section{The Racial Opposition between Blacks and Whites}

After the Civil War broke out, the blacks were liberated, and a large number of blacks began to move into the cities. Initially, the migration of blacks was only carried out in the south, and it was not until the end of the 19th century and the beginning of the 20th century that large-scale migration to other regions began. However, there are many contradictions in the city, and racial discrimination is very serious, especially in the racial discrimination of whites against blacks.

The urbanization of black Americans started in the south.
Before the Civil War, black slaves basically lived in the rural areas of the South. The existence of slavery restricted the development of urbanization in the United States. The "Proclamation on the Emancipation of Black Slaves" promulgated in 1862 liberated more than 4 million black slaves. Although black people have gained freedom, this is only a nominal freedom and equality. American black people have not obtained political rights and land, and continue to be racially discriminated against and oppressed by white people. With the increase of the black population in the city, they occupy some of the resources of the white people, and they also form competition with the white people in their work, which has led to intensified racial conflicts. The characteristics of urban social morphology are manifested in the intensification of apartheid, the city has become a hotbed of racial conflict, an autonomous black community has formed, and the center of southern society has moved from the countryside to the city. Racism has led to the separation of blacks and whites and their activities in different social spheres. The isolation of the southern states is usually accomplished through the legal system and the exclusion of blacks, while the northern states are mainly implemented through customs and traditions. Apartheid puts black families under great economic pressure and social pressure. The racial conflict between blacks and whites still exists so far. Although it has improved greatly, it is also difficult to reconcile. This kind of racism has deeply hurt black people and caused them great suffering.

In The Grace, the most striking example of the two races is the Bacon Rebellion in Virginia in 1676.

Half a dozen years ago an army of blacks, natives, whites, mulattoes-freedmen, slaves and indentured-had waged war against local gentry led by members of that very class... By eliminating manumission, gatherings, travel and bearing arms for black people only; by granting license to any white to kill any black for any reason; bycompensating owners for a slave's maiming or death, they separated and protected all whites from all others forever. ( $\mathrm{p}$ 11)

Taking skin color as a sign to stipulate a person's state of freedom or slavery has become the social foundation of the growing white community in North America. As Morrison said in Playing in the Dark: whiteness and the literary imagination,"Africanism is the vehicle by which the American self knows itself as not enslaved, but free; not repulsive, but desirable; not helpless, but licensed and powerful; not history-less, but historical; not damned, but innocent; not a blind accident of evolution, but a progressive fulfillment of destiny." (69)

In God Help the Child, even black people are categorized by shade of skin, 
Some of you probably think it's a bad thing to group ourselves according to skin color-the lighter, the better-in social clubs, neighborhoods, churches, sororities, even colored schools. But how else can we hold on to a little dignity? How else can you avoid being spit on in a drugstore, shovingelbows at the bus stop, walking in the gutter to let whites have the whole sidewalk, charged a nickel at the grocer's for a paper bag that's free to white shoppers? Let alone all the namecalling. (25)

In the 1880s, a binary community model of black and white isolation was basically formed. In the early days of freedom, blacks lacked experience in social survival, community and family management, daily life arrangements, etc., so they would regard the values, life patterns, and language of whites as the basis for their transformation. After entering 1880, the race relationship between blacks and whites in the southern region of the United States deteriorated day by day. Although the blacks after liberation got rid of the status of slavery, they failed to get rid of the situation of discrimination. After being able to become independent, southern blacks gradually alienated the white community, established their own black communities, and formed their own world. Therefore, the discrimination against blacks by white racists directly led to the emergence of black settlements in cities.

\section{URBAN LANDSCAPE AND ITS METAPHOR}

John Hope Franklin pointed out in From Slavery to Freedom: A history of Negro Americans that in the United States, cities have arisen, and at the same time, black communities in cities have also arisen. Before the blacks were liberated, most of them lived in the rural areas of the South. Only a few blacks live in cities or the north. The status of black slaves is dual. They are both human and the private property of the slave owners. Their clothing, food, shelter, transportation and personal safety are all dependent on the white slave owners. After the blacks left the rural areas and came to the cities after liberation, the first question they faced was the housing problem. However, after they came to the city, they had been liberated and did not get the equality and power they hoped for. They continued to be discriminated against by whites and various unfair treatments in urban life. The black people have been discriminated against and excluded for a long time, mixed with the resentment and fear of the white people. They hope that they can stay away from the white people, escape the control of the white people, and take control of their own lives, so they seek to live with the same race. The ghetto, that is, the black community.

The South is not the only area in the United States that is hostile to blacks, and the North is also hostile to blacks. This is due to the influx of blacks into the cities after the liberation, disturbing the urban life of whites. As a result, the urban racial problems became more serious, and the separation of white and black communities was formed. White people use various methods to restrict the rights and life of black people, which makes black people fall into endless suffering. There are iconic and obvious black and white communities in the city, and the residences of blacks and whites are separated. This is also due to the fact that there are fewer things that can communicate and communicate due to cultural differences. The isolation of residence has led to a reduction in communication, and the cultural differences between blacks and whites have also deepened. But compared with other races, the African culture of blacks is rarely preserved because of the rootlessness of their culture.

In the eyes of blacks, cars and trains represent a status symbol and an advanced way of life. The means of transportation in the novel are all very urban trains and cars. In their opinion, this is a more modern means of transportation. Even Pilate, who likes to wander around in Song of Solomon, "made a decent trip (a train and two cars)" when he arrived in Detroit with his daughter and granddaughter. In Song of Solomon, McCann drove the car and brought his family out to show off his middle-class identity. In Jazz, it is more about the description of the railway as a means of transportation. As an advanced means of transportation, the railway shows different identities in the division of carriages. In Home, blacks also enter the city by car and train.

In The Bluest Eye, the Pecora family chased all the way north from the southern countryside to the city they yearned for. Pecola's mother had never seen so many whites in the South, and had never seen a town with such a strong industrial atmosphere. For her, everything was different from the southern urban landscape: different from the light gray houses where blacks lived, The white people live in a seaview room connected to the beach on the coast. The white people enjoy the blue sea and blue sky and breathe the fresh air, while the black people live under the orange sky near the iron factory. In God Help the Child,Leigh talked to Bride about the streetscape," she described the savvy, the perfect memory, the courage needed for street life. You had to find out where the public toilets were, she said; how to avoid children's services, police, how to escape drunks, dope heads. But knowing where sleep was safe was the most importantthing. " "Corner hookerswere the nicest and the ones who warned her about dangers in their trade" (125) In Tar Baby, JADINE describes the landscape of the big city, and these landscapes give her the feeling of home,"This is home, she thought with an orphan's delight; not Paris, not Baltimore, not Philadelphia. This is home. The city had gone on to something more interesting to it than the black people who had fascinated it a decade ago, but if ever there was a black woman's town, New York was it." 
Even Jadine gave his personal experience in the city as a gift to his son, and took possession of the city."Jadine remembered and loved it all. This would be her city too, her place, the place she spent a whole summer once in love with Oom. Riding the subways looking for his name, first as a talisman, then as a friend and finally as a lover in the tunnels of New York City. And now she would take it; take it and give it to Son." (295)

The road landscape is an important part of the urban landscape. The street is the stage of the city. In "Song of Solomon", at the beginning of the novel, Morrison gave a detailed introduction to the street where the baby's family lived, "They called it Not Doctor Street, and were inclined to call the charity hospital at its northern end No Mercy Hospital since it was 1931, onthe day following Mr. Smith's leap from its cupola, beforethe first colored expectant mother was allowed to give birthinside its wards and not on its steps. (3)"

In Home, the streets are also unsafe. When Frank wanted to escape from the lunatic asylum, the first item he needed was "a pair of shoes" so that he could avoid being caught by the police again and being convicted of vagrancy, "Still, before escape, he would have to get shoes somehow, someway. Walking anywhere in winter without shoes would guarantee his being arrested and back in the ward until he could besentenced for vagrancy. Interesting law, vagrancy, meaning standing outside or walking without clear purpose anywhere. (5)"

\section{THE SPIRITUAL ASPIRATIONS OF URBAN BLACKS: ART}

Every nation will be influenced by the culture of other nations, especially blacks. The culture of other races has a profound influence on them. Blacks are different from other ethnic groups that have migrated to the United States. They came here passively. They discovered their commonalities in the unfamiliar environment of the new world. The integration of heritage and indigenous culture constitutes a way of knowing that is different from other races.In Ethnic America: A History, Thomas Sowell believes that when black people first entered the city, life was very difficult. They have no culture, no financial resources, and are not even familiar with the basic principles of hygiene and social behavior or responsibility. Economic poverty and social status determine the harsh environment of the black community.

Regarding "Jazz", many media commented on it. "Chicago Sun" believes that "Jazz" is Toni Morrison's ten-year brewing work, full of temptation, shocking, and the most fascinating chapter in modern novels. The New York Times believes that Toni Morrison used his impeccable skills in "Jazz" to depict a rough world: the humble and weak came to the bustling city to escape fear, but found a more dangerous self here. The story of "Jazz" takes place in the largest city in the United States-New York. New York is located in the northeastern part of the east coast of the United States. It is a large open city. Blacks have a lot of opportunities to show off. Even in Harlem, where blacks gather, many outstanding black writers and literary works have been born. It is the biggest difference from Detroit, which is also a northern city.After the blacks were brought to the United States, their own racial culture had basically disappeared and merged into the white cultural world. African Americans have a duality. They are neither African nor American. The discrimination and oppression of whites against blacks is historical. Many whites who have immigrated to the United States have a deep conception of the hierarchy. This traditional concept divides the black race into inferior peoples and thus oppresses and exploits them. White people have always regarded themselves as higher than other races, hated the dark complexion of blacks, and considered them to be inferior races. In order to show their Americanization and national identity, the blacks have proved the fallacy of racial inferiority in various ways. They believe that everything about whites is good. "The word 'white' has even become synonymous with all virtues." They can't see the value and brilliance of black culture, they only know that they blindly imitate white culture and lose their own culture.

\section{CONCLUSION}

Morrison's keen touch is manifested in her ability to describe black survival stories in different cities, and she is destined not to become a recorder of a certain city, but to write for the urban conditions of the entire black nation. In Toni Morrison's "Song of Solomon", the author focused his attention on a black middle-class family in a big city, and the place of the story was changed to the American metropolis one-by-one law. The main performance is the protagonist's journey to find roots. In "Jazz", the story takes place in New York, a metropolis in the United States. It describes the experience of a black couple from the countryside to the big city. "Home" continues the urban themes of Song of Solomon and Jazz. It tells the story of a black male returning from the battlefield rushing to save his sister who had been abused in the city. In his urban rush, it shows the entrance The real life situation of black people in the city.

\section{Funding}

This paper is a part of research of the project, "A Study of Urban Writing in Contemporary Black American Fiction (2019-ZZJH-512)", General Project of Humanities and Social Science Research of Henan Provincial Department of Education, Sponsored by Found of General Research Project of Humanities and Social Sciences of Henan Provincial Department of Education. 


\section{REFERENCES}

1. Franklin, John Hope.From Slavery to Freedom: A history of Negro Americans.New York:McGraw-Hill,Inc.,1988.

2. Morrison, Toni. Song of Solomon, New York: Vintage, 2004.

3. ---- The Bluest Eye, New York:Knopf, 2015

4. ---- Home.New York:Knopf, 2012.
5. ---- Tar Baby. New York:Vintage,2004.

6. ---- Beloved. New York:Penguin Group,1998.

7. ---- A Mercy...New York:Knopf, 2008.

8. ---- Jazz. New York:Vintage,1992.

9. ---- God Help the Child.New York:Knopf, 2015.

10. Sowell,Thomas. Ethnic America: A History. By Thomas Sowell.New York: Basic Books, 1981.

Citation: Shi Long, "Black Urban Writing in Toni Morrison's Novels", American Research Journal of English and Literature, Vol 7, no. 1, 2021, pp. 1-5.

Copyright ( $@ 2021$ Shi Long, This is an open access article distributed under the Creative Commons Attribution License, which permits unrestricted use, distribution, and reproduction in any medium, provided the original work is properly cited. 